\title{
THE DYNAMICS OF RELIGIOUS FAMILY LIFE FROM A PSYCHOLOGICAL PERSPECTIVE
}

\author{
Ph.D. Elena-Ancuța SANTI ${ }^{1}$, \\ Ph.D. Cosmin SANTI', \\ Faculty of Theology and Sciences of Education, Valahia University of Târgovişte \\ ROMANIA \\ Email1': santi.anca@yahoo.com Email²: santicosmin@yahoo.com
}

\begin{abstract}
Religiosity, as a psychic dimension of human life, gradually forms, stage by stage, in connection with the general development of the being, at different stages of age. From a psychological point of view, one can speak of the existence of an innate religiosity, a religious potential that man has as ontologically given, but spiritual evolution and perfection is continuous throughout his life. Childhood, adolescence, maturity, old age are not only stages of the ontogenetic development of the human being, but they are also landmarks and thresholds in the formation of a religious dimension, in each of which having proof of the active presence of God in human existence. The child, with its specific innocence and purity, seeks God like he seeks his parents, the teenager calls him with all the power of the inner tumult, the adult refers to God as a good friend, to support and help in difficult moments, and the old man with the wisdom of the years hopes to be close to Him.The grounds of religious life are set inside the family, from parent's patterns of behavior reveal to the child how to behave, how to pray, how to create a relation with God.
\end{abstract}

Keywords: religious life; childhood; adolescence; maturity; old age;

\section{INTRODUCTION}

Throughout its existence, the human being constantly changes, its attitudes evolve, the judgments are transformed, the feelings vary, the personality is structured in a way that beliefs, conceptions and religious behaviors also know an upward path on the axis of time, from innocence and beauty specific to childhood to the wisdom and natural stability of old age. The religious life of a person resembles a sinuous journey, with ups and downs, falls and lifts, questions and answers, doubt and faith.

From the moment the children start to ask questions, search, they want to discover and get to know more and more of everything that surrounds them. Their curiosity is unstoppable when they want to find out about angels, God, eternal life or anything related to supernatural reality, all the more so since they can't perceive sensory this spiritual dimension. The evolution of the moral and religious life of children is achieved in relation to the psychological development, each age stage being characterized by a specific religiosity (Cuciuc, 2006, p. 33). The child is born with a religious potential in the soul (Anghelescu, 1939 , p. 45), but this religiosity can become active and develop according to the family that may or may not be religious, to the education that is sometimes devoid of values and even the happenings through which it passes during life. Thus, some know God earlier, since childhood, others at some point in life, but there are also some who discover Him at the end of earthly life. 
It is known that religious sentiment is innate, but the importance of the child's environment cannot be denied: in a religious family, the child will develop real religious feelings and attitudes, in a laic family, the religious sense of the child will fade, disappear.

\section{RELIGIOUS DEVELOPMENT IN CHILDHOOD}

During childhood, God is perceived in an anthropomorphic vision, like a parent, whom the child loves but fears. Even if he does not see it, the child believes that God exists, because his parents also believe, and because his thinking at this age has a magical character, it constitutes the premises of a strong belief. The prayer of the children is simple, lacking in distrust or doubt, is the purest prayer, most sincere and innocent, in simple words concealing thoughts and great desires springing from the heart. A child praying is certain that someone will hear his prayer. He does not believe he can be heard, but he knows, he has the confidence, the belief that the One to whom he addresses by prayer will answer him. At this age, prayer does not know the doubt, the child expects God to answer, like he knows his mother or father are fulfilling his requests. The child lives the religion by the fact that the family to which it belongs also lives in it; inspires the religious breath from the atmosphere of the parental home and is so influenced by the first impressions acquired in the family environment that these are generally decisive for their whole life (Bologa, 1930, p. 61).

Elementary school age (6-10 years) represents a step or a stage of transition from concrete thinking, intuitive-practical from the symbolic phase to complex operative thinking, logical operations, and then to a theoretical and social thinking (Buzalic, Buzalic, 2010, p. 222), and has as type of fundamental activity learning. If the child's first knowledge of God comes from the family, at this age he begins to learn in the institutionalized environment of the school. His psychic activity is experiencing extraordinary development, which favors both mental and moral-religious acquisition. After the age of 7, the child's religiosity begins to develop, the specific age-specific magical thinking is gradually replaced, and the fantastic retreats and remains merely an instrument of imaginary life. Religion begins to be alive, not just a rule of life, but life itself (Buzalic, Buzalic, 2010, p. 222). The child's prayer is more personal, an expression of one's own thoughts, accompanied by emotions and feelings. The child begins to understand the religious ceremonies he attends, thus laying the foundation for his religiosity.

\section{ADOLESCENTS AND RELIGION}

Then comes the adolescence (from the age of 14), a stage characterized by the great questions of life and great doubts that upsurge and fundamentally restores any vision of life; teenagers, with their skepticism, seek to understand as much as possible and to penetrate the spiritual reality as much as possible in order to define and organize their own self, individuality, feelings and feelings. The adolescent's need to understand may resemble the strong thirst felt on a hot summer day.

Adolescence is the age at which everything, the whole universe is viewed from a different perspective, old knowledge and ideas are reanalyzed and selected, now there is a true inner revolution, stimulated by the force of affections and feelings that until now were latent and bursting with all their might. That's why teenagers make decisions under the momentum of impulse and under the heat of feelings. This character of lack of stability and extreme criticism does not exclude the religious dimension of this age. Allport (1961, p. 125) talks about an identity crisis that occurs at this age when the adolescent seeks himself, tries to discover himself and to understand himself, to self-understand and to form his personal self; in this structuring process, they constantly oscillate, their attitude often has an extremist tendency, adolescents actually seek their limits, test their psychic forces, and only 
accept the values and principles they have passed through the filter of their own personality and which correspond at that moment with their vision or conception of the world and life.

Also during this period in the axiological hierarchy of the teenager there are some changes, in the sense that the family is no longer the center or the point of gravity, this role belongs to the group of friends, that is why the values and principles promoted in the family are surpassed by the ones promoted in the group of belonging, parental patterns of behavior lose importance, in favor of those found in the group of friends. Teenagers often feel misunderstood by the family and seek to be in the group of peers, being brought together by the same needs (intellectual, emotional, cognitive etc.), therefore they tend to reject everything related to constraints, limits or behavioral norms, the freedom they speak is understood as the opposite of any border.

Being at the age when in terms of cognitive development important quantitative and qualitative changes occur when their thinking becomes an abstract one, adolescents seek to understand the divine mystery, which they do not always succeed, and there is now the risk of a loss of faith (Catalan, p. 151), or, on the contrary, may constitute the basic step in the formation of an adult belief; therefore, this is a crucial moment in the process of forming a true, authentic faith. That is why adolescents are often in a hurry to self-definition of atheists, often for internal psychic reasons (such as the desire to stand out, to "break patterns" or to shock), assuming a status on which they will come back later, after overcoming this age. Maurice Dubesse (1962, p. 114) argues that adolescence or youth is extremely important as a segment that makes the transition from the age of innocence, childhood to maturity, the stage in which spiritual mutations occur which contribute significantly to the orientation, commitment and preparation for life: now is the time when it is usually lost, gained or faith is being built.

Around the age of 18-19 years appears a particular attraction towards religion, a tendency to approach the highest moral values, is the most important stage in the process of religious maturity, decisive in terms of future religion. Now is outlined the proper perception of God and of the religious cult (Buzalic, Buzalic, 2010, p. 227)

\section{ADULTHOOD AND SPIRITUALITY}

Maturity or adulthood brings rest, easement of feelings, of beliefs and attitudes, because this is the stage in which every human being discovers and accepts himself as he is, relates to himself, to others, in a different way than any other age, with responsibility and balance. But adulthood does not necessarily mean an adult religion or belief. Psychology considers that the adult is the individual who, by discovering to a certain point the resources of his own personality, is able to know his internal limits, possibilities, capacities and resources, and is able to orient them in a clear direction, to achieve a predetermined goal or target, acting consciously and rationally. The adult is or must be responsible for its existence and assume its decisions, acts or behaviors in any sphere of activity.

The relationship or bond of the adult, in general with God is within the bounds of these particularities, characterized by a responsible assumption of the status of believer or unbeliever, choice according to which specific behaviors or attitudes are adopted. The adult who believes himself to be believer in fact makes a sincere adherence to the plan of spiritual existence and relates himself, his life and work to this dimension, unlike the one who considers the divine reality to be outside the human existential plane, or even there is not at all. Some adults believe, but do not admit and confess this faith than maybe in times of struggle of life, when they experience real shocks or religious earthquakes (illnesses, 
sufferings, losses, etc.), others believe and practice the precepts of their faith by going to the Church, praying they are doing good deeds, and others do not believe and do not want to accept or bring into their life religion. Every man is unique, so is how he relates to God and to life. Personal growth and religious growth create the feeling of fulfillment, bringing happiness and inner well-being, reflecting in relationships with others in society; a spiritually accomplished individual is positive, lives in a state of safety and selfreconciliation, first and foremost, but also with others, and becomes able to establish a clear purpose of his own life that makes sense of his existence. Religious maturity is characterized by a proper orientation towards religious values and by a normal perception of God, involves an interpenetration of reason and sentiment, harmonizing between the rational living of religious values and the correct perception of their subordinate obligations (Buzalic, Buzalic, 2010, p. 210). Also, religious maturity means as well a developed moral consciousness, capable of delimiting goodwill and influencing behavior towards the choice of personal and collective good.

Maturity or adult age is the period of maximum activity of the individual, burdened by responsibilities (family, service, social), events, experiences; to be able to cope with it, the adult usually seeks a routine, a way to relieve his existence, which is sometimes reflected in his relationship with God. Caught by the worries of the day, he often forgets to pray or do things because he needs it, not because he feels, so his faith enters a straight path without climbs, which, as St. Paul says, is actually a slip, a fall, because in faith, when you do not climb, you fall (I. Corinthians, 10, 12). At the same time, adults are responsible for what they convey to their children, the belief they have and manifest depends on the religious development of their children. It is known that in childhood, which is the stage with the greatest impact in the development of religious life, the pattern of behavior taken is that of the parents, the child being often the mirror of the family in which he lives. Thus, the adult has the difficult task of conveying and shaping the personality of the children in the lines of true spirituality.

\section{OLD AGE AND RELATIONSHIP WITH GOD}

Old age is characterized by a special relationship with God, on another level, dominated by deep feelings and deep experiences of acceptance and dedication, resignation to life that has passed and hope in future life. There is a predisposition to meditating the Truth and the Transcendent, the attraction to the spiritual world, which corresponds to the instinct of the deity in the Freudian conception.

If in the past the old age was associated with wisdom, the experience of authentic life, today things are slightly different, due to the explosion of information, transformations in all plans, profound changes in the directions of thought and evolution, which leads to a devaluation and a loss of the true landmarks. The treasure of true faith has always been passed on to younger generations through the voice and personal example of the elders. The preservation of cultural and religious traditions is due to them, our grandparents who are the true pillars of Orthodox faith. They are the ones who teach grandchildren the first prayer or how to make the mark of the Holy Cross, why go to the Church and how to behave. In traditional Romanian society, grandparents have a significant role in forming the religious sense of the younger generation. On a personal mental plan, faith helps the elderly overcome difficult obstacles, such as the retirement threshold, inherent illnesses, the loss of a partner or even the near end of life. Faith brings in the soul of old acceptance, positive resignation, hope, a better moral and inner power, motivation to live and overcome weaknesses and 
sufferings, desire to unite with God, and understanding of death not as an end but as a pass to another world.

The dynamics of the religious life of the human being depends, apart from the stage development characteristic of the age stages, by several factors: the social, cultural, ethnic, educational environment, health, promoted intrafamilial values, unforeseen events and events, changes in the living environment and society as a whole, etc.

Family is the frame in which the child is born and on which all his life depends. Here he discovers the world and learns to love, to be loved, to form as a person, and the whole family is responsible for the connection that takes place between children and God. Psychologists who have researched this area claim that there is a spontaneous, inborn religion of the child, a religious potential that every being has since birth, but if the family environment is not fertile to spiritual growth, it will be lost as a religious person, regressing. On the religiosity of the family depends the formation of the child as a true believer, or as a skeptical and unbelieving person and a spiritual relationship.

The awakening of the existing religious sense as potentially latent to the human being at an early age is achieved if, during the first years of life, the child hears the name of God, and if in a Christian context he hears it pronounced as "Dad," will obviously understand it in relation to his experience. The God the child will imagine will undoubtedly have the characteristics of the father (or mother) (Catalan, 1997, p. 149), but will gradually come to truly reveal God. The child assimilates from their parents' behavior not just their ideas and beliefs, but especially the attitudes and religious feelings they directly observe: for example, if a child sees his parents praying, so does he. This places the premise of an intrinsic religious motivation, which is the foundation of true faith.

The religious experience in the child's life begins with the moment when he becomes aware of his subjective experiences, because the experience relates to the inner life of the individual. For preschool children, religious experience is dependent on others, especially family, as the first socializing and training instance, in which they come into contact with the religious universe. Through imitation, the child takes on the models seen in the family, and the tendency of any family is to convey faith or lack of faith to children.

The family represents the fundamental framework with a major role in the religious life of the individual, at least for the first part of his / her childhood (up to 7 years, the age at which he / she goes to school). All the religion of the child depends on the religiosity of the family environment. As is the faith of the fathers, so is the faith of the children; by the way this faith lives and manifests itself in the family environment, so lives and manifests its faith and child. The child's religion is the mirroring of the family's religiosity. Nothing can alter the religious life of the child if the family is permeated by the religious spirit. L. Bologa (1930, p. 18) appreciates that the family has the possibility to influence and at the same time determine the way of religious life through the following three means:

$>$ through the family atmosphere;

$>$ through religious practices or customs in the family;

$>$ through systematic or occasional religious education in the family.

Religious atmosphere influences the development of religious life, the child often identifies this atmosphere with the moral atmosphere. To be good, to be right, not to speak bad, etc., means to be religious (Bologa, 1930, p. 19). In the family, the child learns how to worship, how to say a prayer, although there are also families at the opposite pole, where religious indifference or even anti-religion is specific. 
Through his research, L. Bologa (1930, p. 19) shows that, with respect to the importance of the family atmosphere in the development of the child's religiosity, $96,58 \%$ of the subjects in whose families there was a religious atmosphere, 93.16\% subjects showed a developed religiosity, only $3.43 \%$ remaining indifferent to the positive influence of the family atmosphere. Of the $98,41 \%$ of the subjects in whose families the religious practices were fulfilled, 91, 58\% were positively influenced, and $6,86 \%$ remained indifferent. Ordinary religious practices in the family are closely related to religious education. The family urges the child to fulfill religious practices, highlighting their importance, for example, the child is urged to say prayer in the evening, for the "guardian angel to defend him overnight". Thus, the number of those left indifferent to religious education is reduced by $7,52 \%$ of those involved in the research. By comparing the results, we can deduce that in the family, for the religious formation of the child, the most important role has the religious atmosphere, followed by religious practices and, in the third place, religious education.

\section{CONCLUSIONS}

A. Godin $(1963$, p. 9) argues that the God of the Fathers is the God of the children, referring to the fact that the parents are responsible and obliged to facilitate the contact of the children with everything belonging to the religious sphere, the family having the function of transmitting the inheritance religious and his faith. Gradually, the God of his parents becomes his God, the child who prays because so does his mother, believes in God because he sees the strength of the faith of the parents, the power of the example being for children, in general, more important than a thousand words. Imitation is the basis for learning at young ages, so children assimilate the behaviors and attitudes they see to family members or significant people in their lives.

Thus, primordial relationships with father and mother determine, beyond any explicit teaching, subsequent attitudes towards God, the family cell will be the matrix of religious conduct or antireligious reactions (Catalan, 1997, p. 149). In conclusion, we can state that religion is imprinted in the human being, it is an ontological given and it manifests in each age stage differently depending on the psychic development and on the general evolution of the individual, the educational context and the living environment, with outbursts, shocks and returns or with definitive losses. Religion is a reality, a dimension of life, and we each choose how to relate to it and how to make God a living part of us.

\section{BIBLIOGRAPHY:}

[1] Allport G.W. (1961). Pattern and Growth in Personality, New York: Holt, Rinehart \& Winston.

[2] Anghelescu, A. (1939). Psihologia religioasă a adolescentului cu aplicaţiune la învăţământul religios, Brăila.

[3] Bologa, L. (1930). Psihologia vieţii religioase, Cluj: Editura Cartea Românească.

[4] Buzalic Al., Buzalic A. (2010). Psihologia religiei, Târgu Lăpuş: Editura Galaxia Gutenberg.

[5] Catalan, J.F. (1997). Omul şi religia sa. O perspectivă psihologică, traducere de Andreea Bratosin, Bucureşti: Editura Polimark.

[6] Cuciuc, C. (2006). Sociologia religiilor, ediţia a III-a, Bucureşti: Editura Fundaţiei România de Mâine.

[7] Cucoş, C. (2009). Educaţia religioasă. Repere teoretice şi metodice, Iaşi: Editura Polirom.

[8] Debesse, M. (1962). L'Adolescence, Paris: PUF.

[9] Godin, A. (1963). Le Dieu des parents et le Dieu des enfants. Trois études de psychologie religieuses, Paris: Casternan.

[10] Wright, H. (2007). Spiritual Development in Childhood and Adolescence, Expository Times, 118 (6), pp. 307-308. 